\title{
Diagnosis and surgical treatment of mucocele: Clinical case report
}

\author{
Diagnóstico e tratamento cirúrgico de Mucocele: Relato de caso clínico \\ Diagnóstico y tratamiento quirúrgico del mucocele: Informe de um caso clínico
}

Received: 06/16/2021 | Reviewed: 06/20/2021 | Accept: 06/24/2021 | Published: 07/10/2021

\author{
Thais Maibashi Minomi \\ ORCID: https://orcid.org/0000-0003-2704-7047 \\ Araçatuba School of Dentistry, Brazil \\ E-mail: thaisminomi@hotmail.com \\ Vinícius Franzão Ganzaroli \\ ORCID: https://orcid.org/0000-0002-8590-4978 \\ Araçatuba School of Dentistry, Brazil \\ E-mail: viníciusfganzaroli@ hotmail.com \\ Daniela Ponzoni \\ ORCID: https://orcid.org/0000-0001-5928-0914 \\ Araçatuba School of Dentistry, Brazil \\ E-mail: daniela.ponzoni@unesp.br
}

\begin{abstract}
Mucoceles are benign pseudocystic lesions, whose main etiological factors are trauma and ductal obstruction, with the rupture of a duct in the salivary gland and leakage of mucin into the adjacent soft tissues. They are characterized by being asymptomatic and often present spontaneous rupture. Histologically, they are made up of a cystic wall devoid of epithelium, outlined by granulation tissue and inflammatory cells. Mucoceles usually present as dome-shaped mucous swellings, which can vary in size from 1 to $2 \mathrm{~mm}$ to a few centimeters, characterized as a floating lesion, although some may be firm on palpation. The evolution time reported for this lesion varies from a few days to several years, and the most common site of involvement for this phenomenon is the lower lip. Some mucoceles are self-limiting, with spontaneous rupture and scarring, however, many of these lesions are chronic in nature, and local surgical excision may be necessary. The aim of this study was report a clinical case of mucocele on the lower lip. The surgical removal of the mucocele proved to be an effective and safe technique in the case in question, enabling the histopathological diagnosis of the lesion.
\end{abstract}

Keywords: Mucocele; Oral lesions; Surgery.

\section{Resumo}

Mucoceles são lesões pseudocísticas benignas, que possuem como principais fatores etiológicos o trauma e a obstrução ductal, ocorrendo a ruptura de um ducto da glândula salivar e o extravasamento da mucina para dentro dos tecidos moles adjacentes. Caracterizam-se por serem assintomáticas e, muitas vezes, apresentam rompimento espontâneo. Histologicamente, são constituídas por uma parede cística desprovida de epitélio, delimitada por tecido de granulação e células inflamatórias. As mucoceles geralmente se apresentam como aumentos de volume mucosos em forma de cúpula, que podem ter seus tamanhos variando de 1 a $2 \mathrm{~mm}$ a alguns centímetros, caracterizada como uma lesão flutuante, embora algumas possam ser firmes a palpação. O tempo de evolução relatado para esta lesão varia de poucos dias a diversos anos, e o sítio mais comum de envolvimento para esse fenômeno é o lábio inferior. Algumas mucoceles são autolimitantes, com rompimento e cicatrização espontâneos, entretanto, muitas dessas lesões são de natureza crônica, e a excisão cirúrgica local se faz necessária. Este estudo teve por objetivo relatar um caso clínico de mucocele em lábio inferior. Conclui-se que a remoção cirúrgica da mucocele, demonstrou-se uma técnica efetiva e segura no caso em questão, permitindo o diagnóstico histopatológico da lesão.

Palavras-chave: Mucocele; Lesões bucais; Cirurgia.

\section{Resumen}

Los mucoceles son lesiones pseudoquísticas benignas, cuyos principales factores etiológicos son el traumatismo y la obstrucción ductal, con rotura de un conducto en la glándula salival y fuga de mucina a los tejidos blandos adyacentes. Se caracterizan por ser asintomáticos y suelen presentar rotura espontánea. Histológicamente, están constituidos por una pared quística desprovista de epitelio, delimitada por tejido de granulación y células inflamatorias. Los mucoceles suelen presentarse como tumefacciones mucosas en forma de cúpula, que pueden variar en tamaño desde 1 a $2 \mathrm{~mm}$ hasta unos pocos centímetros, caracterizadas como una lesión flotante, aunque algunas pueden ser firmes a la palpación. El tiempo de evolución reportado para esta lesión varía de unos días a varios años, y el sitio más común de afectación de este fenómeno es el labio inferior. Algunos mucoceles son autolimitados, con rotura espontánea y cicatrización, sin embargo, muchas de estas lesiones son de naturaleza crónica y es necesaria la escisión quirúrgica 
local. Este estudio tuvo como objetivo reportar un caso clínico de mucocele en el labio inferior. Se concluye que la extirpación quirúrgica de la lesión de mucocele, resultó ser una técnica eficaz y segura en el caso en cuestión, permitiendo el diagnóstico histopatológico de la lesión.

Palabras clave: Mucocele; Lesiones bucales; Cirugía.

\section{Introduction}

A mucocele is a phenomenon of retention and extravasation of mucus into adjacent soft tissues. Its best-documented and accepted main etiological factor is mechanical trauma, especially bite, which compresses and collapses the ducts of the minor salivary glands, which continue to produce saliva, thus increasing the cyst's diameter (Santos et al., 2013; Neville et al., 2016).

Despite experimental and clinical evidence showing trauma as the most likely cause of mucoceles, it is important to emphasize that, in some cases, mucoceles can be associated with congenital lesions, Sjögren's Syndrome and cystic fibrosis. It is possible that non-traumatic predisposing factors may also contribute to the development of this injury (Santos et al., 2013).

Clinically, it presents as a single or multiple smooth, spherical, painless nodule, with a translucent blue to pink coloration, with a sessile base and similar to the color of the mucosa (Santos et al., 2013; Bezerra et al., 2016; Neville et al., 2016; Choi et al., 2019). Studies of cases of lesions that have been shown to result from trauma have reported that the lower lip is not only the most common location for mucoceles, but also the site of greatest involvement of all soft tissue injuries associated with trauma (Bezerra et al., 2016; Neville et al., 2016). Regarding the gender of patients, there is no difference in its prevalence, affecting patients of all ages, with greater frequency in the second decade of life (Bravo et al., 2018; Neville et al., 2016).

Histologically, it is made up of a cystic wall devoid of epithelium, delimited by granulation tissue and inflammatory cells, including numerous foamy histiocytes (macrophages), due to mucus leakage, causing an associated response of the inflamed granulation tissue (Chi et al., 2011).

They are called pseudocysts, as they do not have an epithelial lining wall and their evolution can be divided into three phases. In the first, there is the shedding of mucin into the surrounding tissue, where some leukocytes and histiocytes are seen. In the second phase, the granulation reaction appears due to the presence of histiocytes, macrophages and multinucleated giant cells associated with the foreign body reaction. Later, in the third stage, there is the formation of a pseudocapsule without epithelium around the mucosa, due to connective tissue cells (Chi et al., 2011; Bezerra et al., 2016).

\section{Methodology}

The present study is a descriptive qualitative case report combined with a brief literature review with the available relevant data, regarding the characteristics, etiology and treatment of the pathology. The clinical case presented is of a 30-yearold male patient Caucasian, with suspected lower lip mucocele, who attended the Oral and Maxillofacial Surgery and Traumatology clinic of the Araçatuba Dental School - UNESP. The patient signed an informed consent form (Pereira et al., 2018).

\section{Literature Review}

Mucoceles are relatively frequent pathologies resulting from the minor salivary glands and can occur through two distinct mechanisms: extravasation and mucus retention. Extravasation corresponds to the leakage of mucus from the salivary glands to the adjacent tissue and is the main cause of mucoceles with mechanical trauma as the main cause. Retention occurs less frequently, and is caused by duct obstruction by sialolith or stenosis, and generally affects older individuals (Santos et al., 2013; More et al., 2014; Neville et al., 2016; Essaket et al., 2020). 
The most common lesions occur in the inner portion of the lower lip, although they can also be found in regions where the minor salivary glands are present (Valério et al., 2013; Bezerra et al., 2016; Neville et al., 2016; Garrote et al., 2020). They are slow-growing and generally rounded, slightly bluish or translucent when close to the surface of the epithelial tissue and, the deeper they are in the connective tissue, the more they resemble a mucosa-like nodule (Santos et al., 2013; Valério et al., 2013; Bezerra et al., 2016; Neville et al., 2016; Choi et al., 2019).

Some mucoceles are self-limiting and their rupture and healing are spontaneous. However, many of these lesions are chronic in nature and the most indicated technique is local surgical excision (Ata-Ali et al., 2010). To minimize the risk of recurrence, any minor salivary gland that may be located within the lesion should be removed (Barki., 2016; Meinerz et al., 2019), and the excised tissue submitted to histopathological evaluation to confirm the diagnosis and rule out the possibility of salivary gland tumors (Meinerz et al., 2019). One strategy to avoid recurrences is the excision of small lesions down to the muscle line, together with the marginal salivary gland tissue (Barki., 2016; Bravo et al., 2018). For large lesions, marsupialization will help prevent damage to vital structures such as the labial branch of the mental nerve. Micromarsupialization can be considered as an alternative surgical method in the case of pediatric patients, as it is a simple, non-traumatic, relatively painless technique with less chance of recurrence (Huzaifa et al., 2021).

Other surgical methods of treating oral mucoceles are $\mathrm{CO}_{2}$ laser ablation, cryosurgery using liquid nitrogen and electrocautery, which decrease the chances of recurrence and complications. Patients who cannot tolerate long procedures benefit from such procedures. However, these techniques do not allow histopathological examination of the lesion and are somewhat controversial (Santos et al., 2013; Biléco et al., 2013; Bezerra et al., 2016; Barki., 2016; Tsunoda et al., 2020; Huzaifa et al., 2021). Furthermore, the treatment of mucoceles by sclerotherapy with intracavitary injection of promethazine hydrochloride has been shown to be effective and less invasive. However, some patients are allergic to promethazine (Huang et al., 2021; Chen., 2020).

Therefore, although surgical excision is the most recommended method, the clinical characteristics and age of the patient are important factors to consider, since the possibility of recurrence of the lesion is common mainly among young people, and the surgeon should select the most appropriate therapeutic option for each case (Choi et al., 2019; Garrote et al., 2020).

\section{Case report}

A 30-year-old male patient Caucasian no systemic comorbidities was attended the Oral and Maxillofacial Surgery and Traumatology clinic of the Araçatuba Dental School, reporting that 14 days previously, after biting on a snack, a "bubble" appeared on his lower lip. The clinical examination revealed a circumscribed lesion, similar to mucosa, with a sessile base, firm to palpation, $1 \mathrm{~cm}$ in diameter, located on the left side of the lower lip, with a diagnostic hypothesis of mucocele (Figure 1). 
Figure 1: Clinical aspect of the lesion.

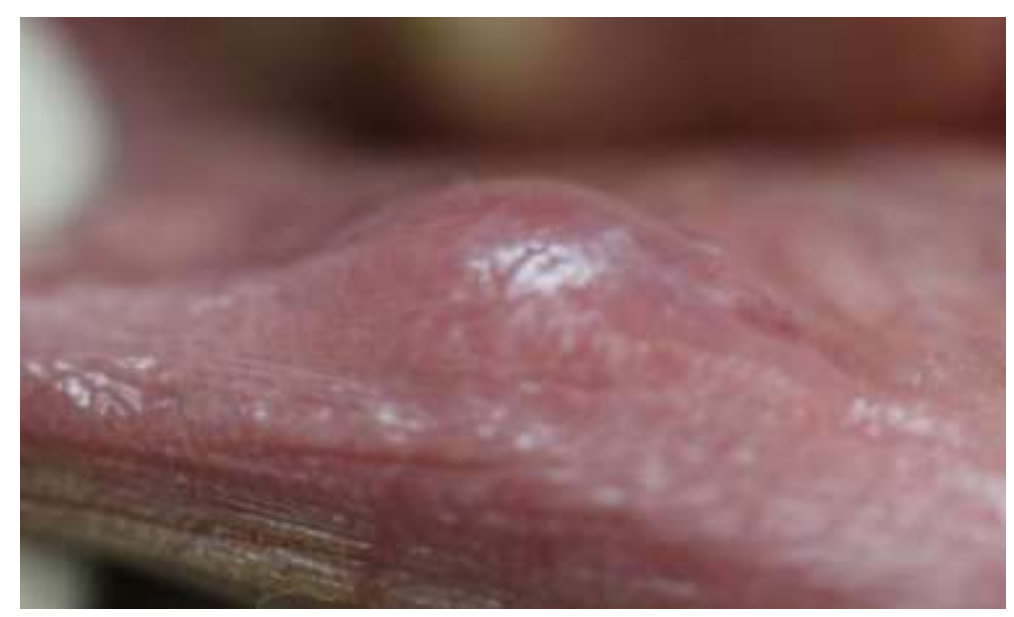

Source: Authors.

After anamnesis and detailed clinical examination, mucocele of the lower lip was diagnosed. Because the lesion did not spontaneously rupture, surgical excision was chosen. For this purpose, antisepsis of the oral mucosa was carried out with chlorhexidine $0.12 \%$ and of the local skin with polyvinyl iodopovidone (PVPI). A topical anesthesia with Benzotop ${ }^{\circledR}$ (benzocaine $200 \mathrm{mg} / \mathrm{g}$ ) was followed by local infiltrative anesthesia with $2 \%$ mepivacaine and 1:100,000 epinephrine around the lesion. This was followed by an elliptical incision with a No. 15 scalpel blade and tissue divulsion with blunt-tipped scissors, in order to atraumatically detach the lesion from the surrounding tissue. Then, excision of the lesion was performed with removal of adjacent accessory glands, in order to prevent recurrence (Figures 2 and 3 ).

Figure 2: Removed lesion.

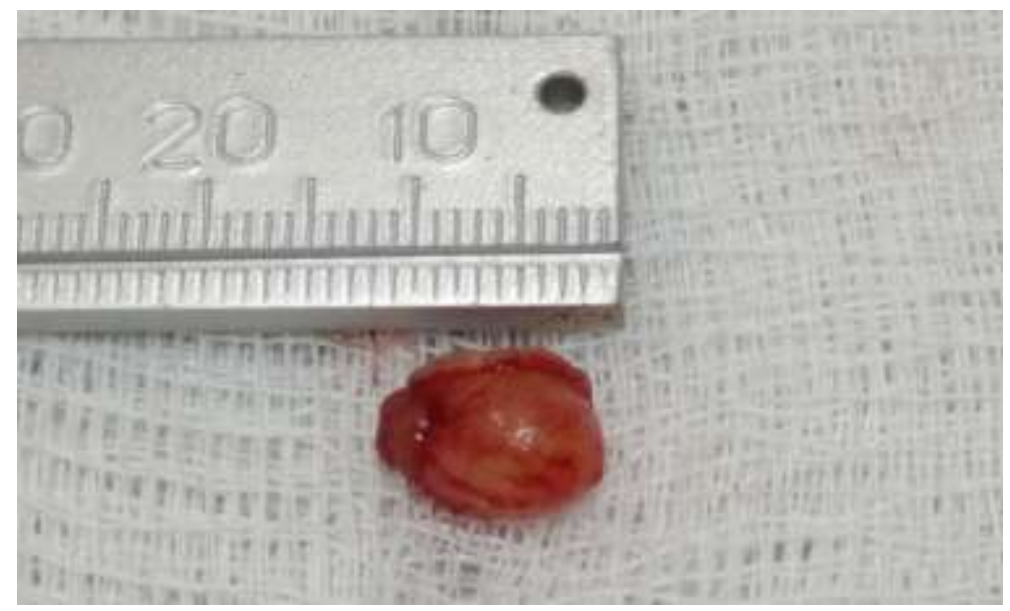

Source: Authors. 
Figure 3: Aspect of the lower lip after removal of the lesion.

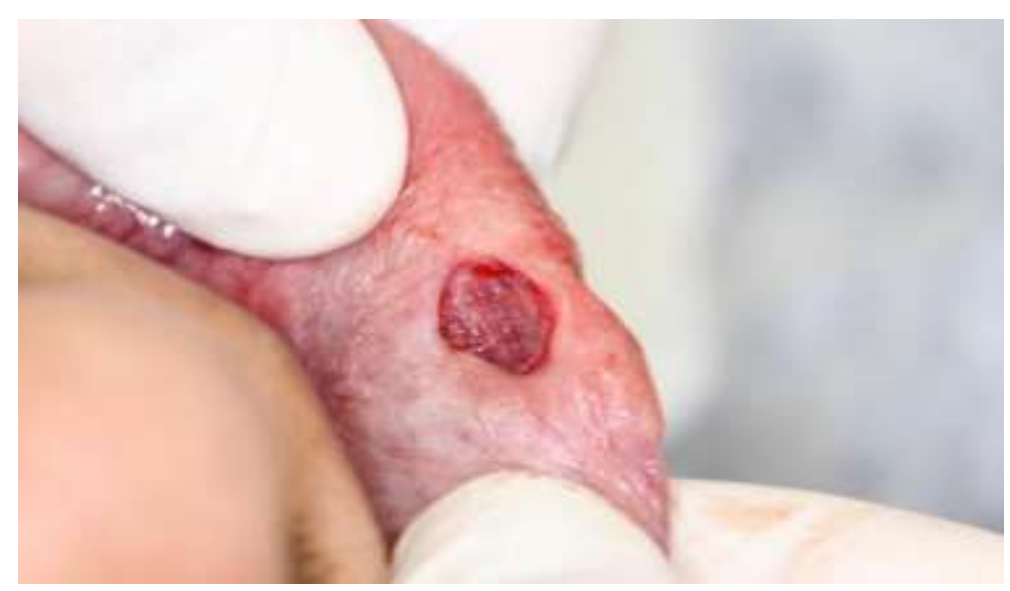

Source: Authors.

The procedure was completed with simple stitch suture with 4-0 silk thread (Figure 4). The material was collected and fixed in $10 \%$ formalin and sent for histopathological evaluation. Seven days after surgery, the stitches were removed during a postoperative consultation and the surgical wound was observed to have repaired well (Figure 5). The result of the histopathological examination confirmed the diagnosis of mucus retention (mucocele) (Figure 6 and 7). Since then, the patient has been under follow-up ( 2 years) and there has been no recurrence of the lesion (Figure 8 ).

Figure 4: Suture with 4-0 silk thread.

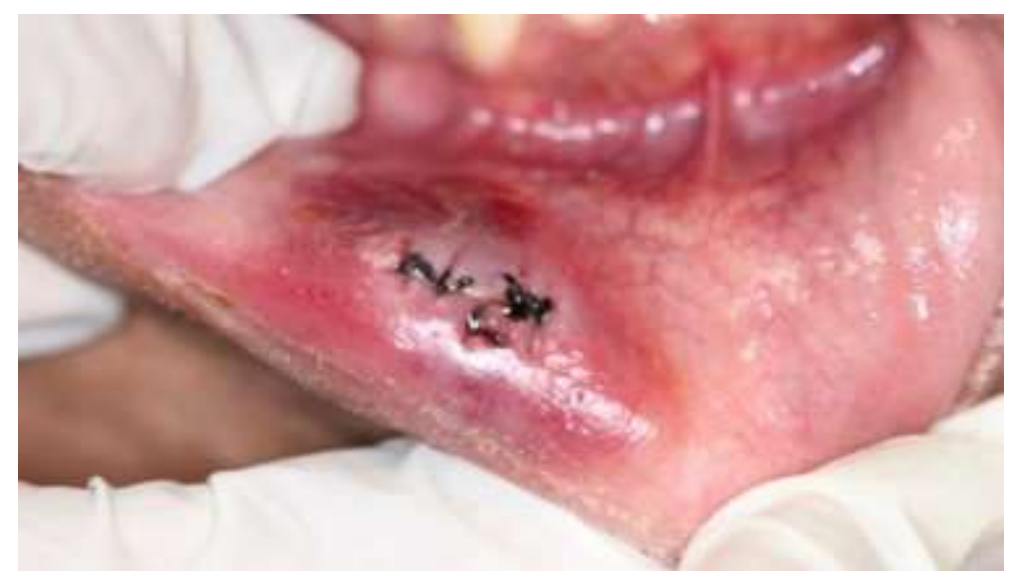

Source: Authors. 
Research, Society and Development, v. 10, n. 8, e19010817289, 2021

(CC BY 4.0) | ISSN 2525-3409 | DOI: http://dx.doi.org/10.33448/rsd-v10i8.17289

Figure 5: 7 days after surgery.

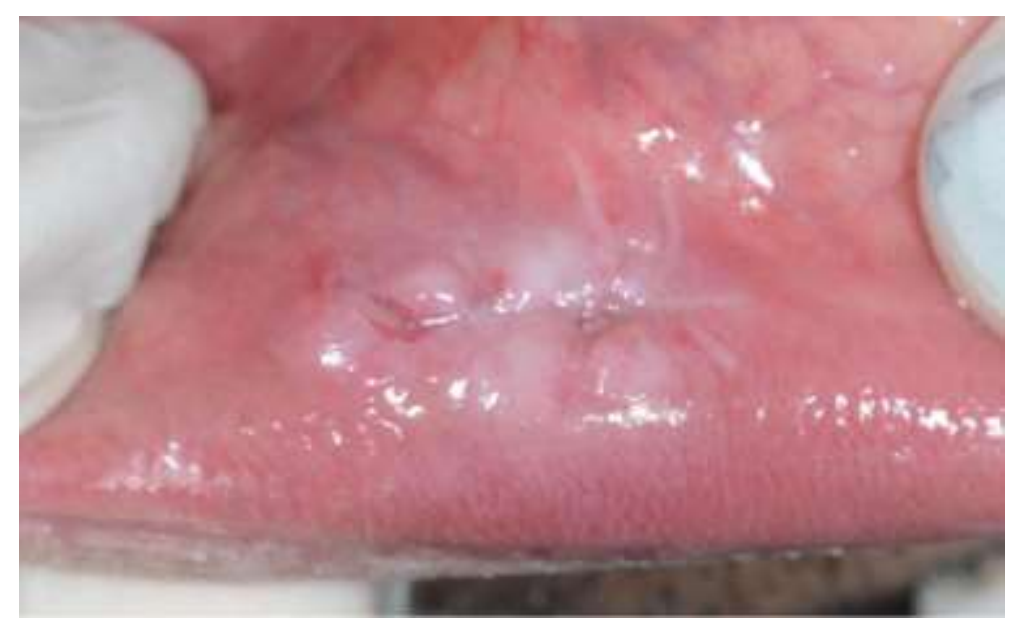

Source: Authors.

Figure 6: Histopathological diagnosis.

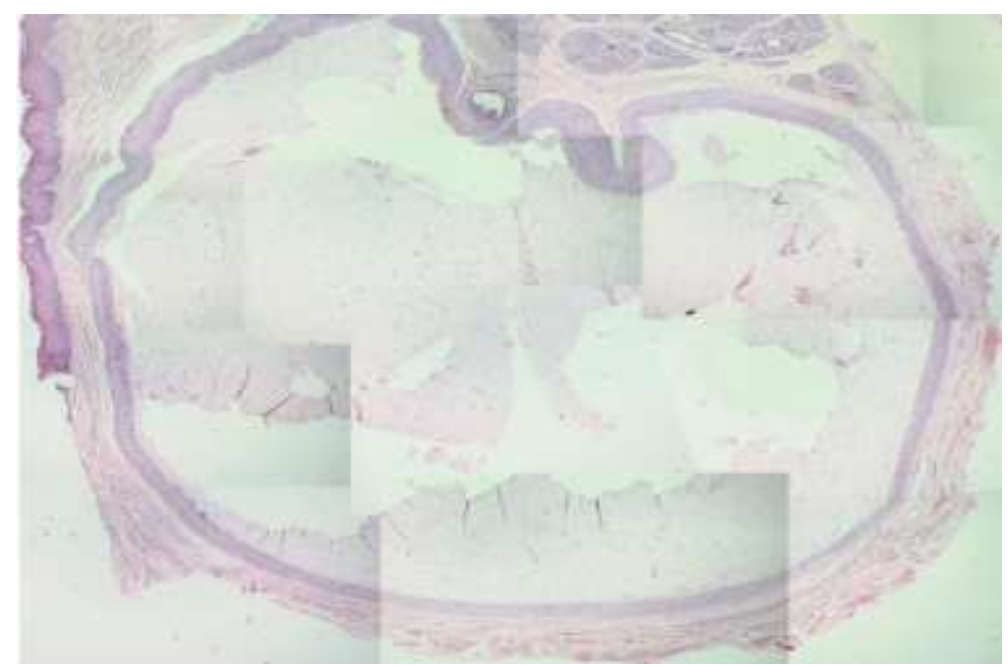

Source: Authors.

Figure 7: Transitional area of the edge of the lesion.

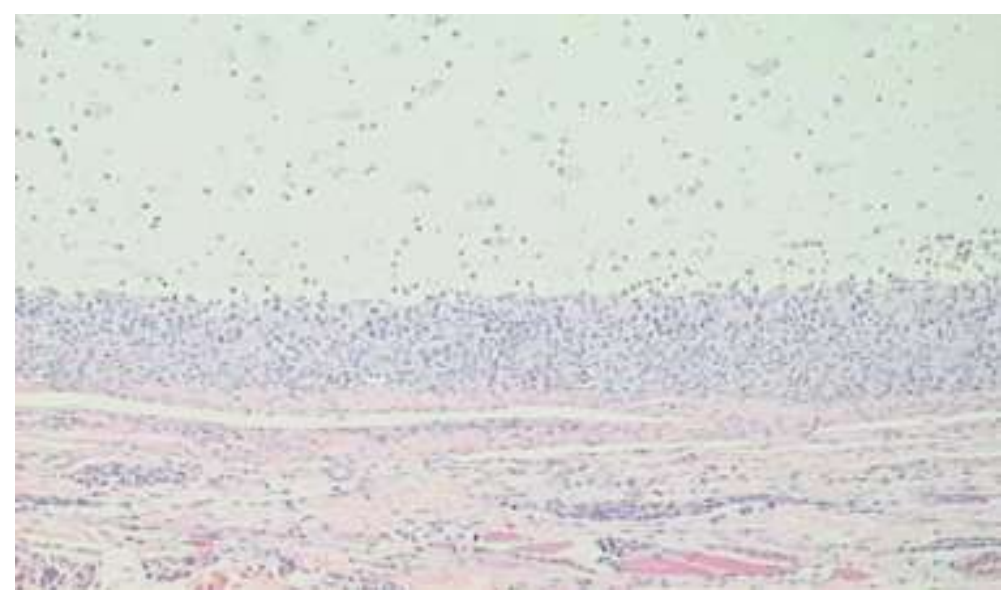

Source: Authors. 
Figure 8: Two years follow-up, no recurrence.

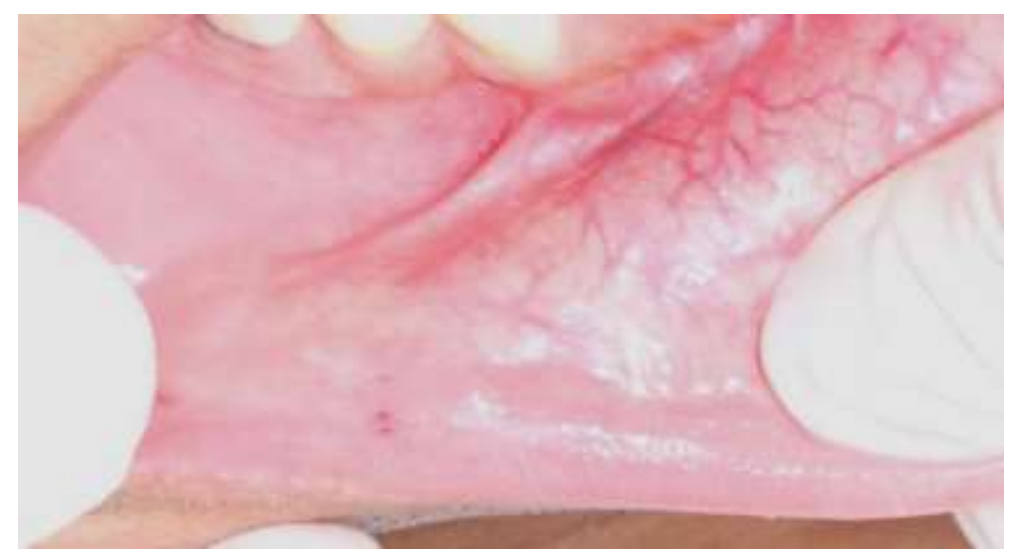

Source: Authors.

\section{Discussion}

There is no difference in incidence regarding the gender of patients (Bezerra et al., 2016), and this condition affects patients of all ages, especially in the second decade of life (Neville et al., 2016). In the case presented, the patient was a male in the third decade of life.

For the differential diagnosis of mucoceles, clinical examination is usually carried out; however, it can be confused with other pathologies that affect the oral region depending on its clinical presentation. Therefore, it is important to perform the differential diagnosis of other intraoral lesions, such as hemangioma, lipoma, fibroma, and malignant and benign neoplasms of the salivary gland (Huzaifa et al., 2021).

Most oral mucoceles are asymptomatic superficial lesions, located in tissue strata that is poorly vascularized and with few nervous structures. However, painless lesions which are larger than $1.5 \mathrm{~cm}$ and deeply located in the tissue, may present some sensation of discomfort during speech and/or chewing.

For the patient reported here, conservative surgical treatment with total excision of the lesion followed by histopathological examination was the treatment option chosen, which confirmed the presence of mucocele and the absence of any type of malignant pathology. Among other treatment options reported in the literature are marsupialization, micromarsupialization, electrocauterization, cryosurgery, sclerotherapy, as well as the use of carbon dioxide laser, which does not allow the specimen to be sent for histopathological examination. (Santos et al., 2013; Biléco et al., 2013; Bezerra et al., 2016; Barki., 2016).

\section{Conclusion}

Surgical removal of a lesion that is suspected of being a mucocele is a quick, safe technique that enables histopathological diagnosis. In the clinical case in question, a 2-year follow-up demonstrated that the surgical removal of the lesion was successful and that there were no recurrences.

\section{References}

Ata-Ali, J., Carrillo, C., Bonet, C., Balaguer, J., Peñarrocha, M., \& Peñarrocha, M. (2010). Oral mucocele: review of the literature. J Clin Exp Dent, 2 (1), 1821.

Barki, M. C. L. J. M. (2016). Protocolo Clínico para Diagnóstico e Tratamento de Mucocele e Rânula. CRO-RJ, 33 (11), 28.

Bezerra, T. M. M. (2016). Levantamento epidemiológico de fenômeno de extravasamento de muco de um centro de referência em patologia oral por um período de 43 anos. Braz. J. Otorhinolaryngol, 82 (5), 536-542. 
Research, Society and Development, v. 10, n. 8, e19010817289, 2021

(CC BY 4.0) | ISSN 2525-3409 | DOI: http://dx.doi.org/10.33448/rsd-v10i8.17289

Biléco, D. S., Silva, D. F., Coclete, G. A., Soubhia, A. M. P., Gaetti Jardim Junior, E., \& Castro, A. L. (2013). Mucocele: diagnóstico e tratamento. Arch. Health Investig, 2, 138.

Bravo, F. A. R. (2018). Prevalencia de mucocele en pacientes atendidos en el servicio de cirugía de cabeza, cuello y maxilo - facial del hospital la caleta en los meses de enero a junio, año 2018. http://repositorio.uladech.edu.pe/handle/123456789/6037.

Chen, A. (2020). Preliminary experience with promethazine hydrochloride injection in the sclerotherapy of oral mucocele. Int. J. Oral Maxillofac. Surg, S0901-5027 (20), e30373-8.

Chi, A. C., Lambert III, P. R., Richardson, M. S., \& Neville, B. W. (2011). Oral mucoceles: a clinicopathologic review of 1,824 cases, including unusual variants. Journal of Oral and Maxillofacial Surgery, 69 (4), 1086-1093.

Choi, Y. J., Byun, J. S., Choi, J. K., \& Jung, J. K. (2019). Identification of predictive variables for the recurrence of oral mucocele. Medicina oral, patologia oral y cirugia bucal, 24 (2), e231-5.

Essaket, S., Hakkou, F., \& Chbicheb, S. (2020). Mucocele of the oral mucous membrane. PanAfrican Medical Journal, 35, 140.

Garrote, D. A. S., Franco, M. M. C., Silva, D. F. S., \& Nemezio, M. A. (2020). Mucocele en paciente odontopediátrico: reporte del caso. Research, Society and Development, 9 (10), e1479108224.

Huang, Y., Yang, C., Wang, T., Liu, S., \& Chen, A. (2021). Preliminary experience with promethazine hydrochloride injection in the sclerotherapy of oral mucocele. Int. J. Oral Maxillofac. Surg, 50 (4), 516-521.

Huzaifa, M., \& Soni, A. (2021). Mucocele and Ranula. https://www.ncbi.nlm.nih.gov/books/NBK560855/.

Kanehira, B. T. B., Oliveira, G. S., Pinheiro, T. N., Martins, V. B., \& Oliveira, M. V. (2017). Tratamento cirúrgico de mucocele de tamanho atípico em lábio inferior: relato de caso. Rev. Cir. Traumatol. Buco-Maxilo-Fac, 17 (3), 17-20.

Meinerz, E. D., Piazza, A. C, Santos, J. M., Jaroczewski, C., \& Hentschke, G. S. (2018). Mucocele: revisão de literatura. RMIC, 1 (1). https://ulbracds.com.br/index.php/rmic/article/view/1635.

More, C. B., Bhavsar, K., Varma, S., \& Tailor, M. (2014). Oral mucocele: A clinical and histopathological study. Journal of Oral and Maxillofacial Pathology, 18 (1), 72-77.

Neville, B. W., Damm, D. D., Allen, C. M., \& Chi, A. C. (2016). Patologia Oral \& Maxilofacial (4ª ed.) Elsevier. 860-865.

Pereira, A. S., Shitsuka, D. M., Parreira, F. J., \& Shitsuka, R. (2018). Methodology of cientific research. Santa Maria: UAB / NTE / UFSM. https://repositorio.ufsm.br/bitstream/handle/1/15824/Lic_Computacao_Metodologia-Pesquisa-Cientifica.pdf?sequence=1\&isAllowed=y.

Santos, F. M., Corrêa, F. N. P., \& Corrêa, M. S. N. P. (2013). Mucocele em lábio inferior de adolescente: relato de caso. Rev. Assoc. Paul. Cir. Dent, 67, (3), 230-233.

Tsunoda, N., Kawai, T., Obara, M., Suzuki, S., Miyamoto, I., Takeda, Y., \& Yamada, H. (2020). Analysis of effects and indications of cryosurgery for oral mucoceles. Journal of Stomatology, Oral and Maxillofacial Surgery, 2468-7855 (20), 30160-9.

Valério, R. A., Queiroz, A. M., Romualdo, P. C., Brentegani, L. G., \& Paula-Silva, F. W. G. (2013). Mucocele and fibroma: treatment and clinical features for differential diagnosis. Brazilian Dental Journal, 24 (5), 537-541. 